\title{
EFFECT OF DIFFERENT PLANTING SYSTEM ON SOIL, WATER AND RICE PRODUCTIVITY IN THE NORTHERN PART OF DELTA IN EGYPT
}

\author{
Zayed, B. A. ${ }^{1}$; I. A. EI - Saiad ${ }^{3}$; S. M. Bassiouni ${ }^{1}$ and A. K. Salem ${ }^{2}$ \\ "Corresponding author E-mail: basunyz@yahoo.com \\ 1-Rice Res. and Training Center, Field Crops Res. Institute, ARC, Egypt
}

2- Agronomy Dept., Agric. branch-National Res. Center- Doki- Giza Egypt.

3- Chemical and Physical of Soils Dept, Water and Environment Res. Institute, ARC, Sakha, Kafr El-Sheikh, Egypt

\begin{abstract}
Water scarcity and soil salinity are the main constrains for rice production in Egypt. Rice is the greatest consumer of water among all crops. A system of growing rice on raised beds or levees and system of rice intensification (intermittent irrigation system) where water is applied only in the furrows between beds, is hypothesized to reduce water input for rice. For water saving with considerable rice grain yield under newly reclaimed saline soil, two field experiments were conducted to innovate new rice planting technology at the experimental farm of El Sirw agriculture research station during two successive seasons of, 2011 and 2012. The system of rice cultivation technology were traditional transplanted with watering every four days as traditional methods (control treatment) up to $6 \mathrm{~cm}$ water depth, system of rice intensification (SRI) with intermittent irrigation system, dry rice seed on dry levees with watering as upland crop up to 30 days after sowing then shifting watering every four days up to $1 \mathrm{~cm}$ water depth and transplanted rice on levees with watering every four days up to $1 \mathrm{~cm}$ water depth.

The used variety in this experiment was Giza 178 (drought and salt tolerant Egyptian rice variety). The soil was clayey in texture with salinity level of $6.5 \& 6.0$ $\mathrm{dS} / \mathrm{m}$ in 2011 and 2012 seasons, respectively.

The obtained findings revealed that the different systems of rice planting and technology significantly showed variation in their impact on soil properties, yield and yield attributing characteristics of rice as well as saved water and water productivity in rice crop under such circumstances. SRI had the lowest values of soil EC, soluble cations and anions as well as bulk density in both seasons. Furthermore, SRI gave the highest values of yield and most of yield components as well as chlorophyll content in the leaf at heading without any significant differences with those obtained by Traditional transplanted one. The dry seed on dry levees gave the highest values of soil EC, soluble and anions as well as bulk density and, lowest value of $\mathrm{pH}$ in both seasons followed by transplanted on levees but less than the initial values of them. the system of dry seed on dry levees gave the lowest values of total applied water ( $\left.8899.0 \& 8910.0 \mathrm{~m}^{3} / \mathrm{ha}\right)$ in the first and second seasons, respectively followed by transplanted rice on levees and then SRI in both seasons. In addition, dry seed on dry levees had the highest values of water use efficiency and water saved $(0.87$ and 0.91 as well as 4290) for WUE, water saved in 2011 and 2012 seasons, respectively, followed by rice transplanted on levees and then SRI(Table9). Traditional rice transplanting of flat soil gave the highest values of total applied water (13618 \&13629 $\mathrm{m}^{3} / \mathrm{ha}$ ) and the lowest values of water use efficiency $(0.61$ and 0.64$)$ in the first and second seasons, respectively. Considering soil, yield and water saved, the SRI superior the rest of current investigated system of rice cultivation under present conditions.
\end{abstract}

Keywords: Rice, Water Use Efficiency, SRI, dry seed, soil properties Saline soils. 


\section{INTERODUCTION}

Water available for agriculture is diminishing due to rapid population growth and climate change along with rising demand for food. This is especially true for rice due to urbanization, which has led to an upward shift in demand for rice worldwide as people change their eating habits. Increased rice supply, on the other hand, is constrained due to lack of sufficient water availability as this crop is the largest consumer of water in the agricultural sector. Rice (Oryza sativa L) occupies an important order in the economy of Egypt. It not only meets the total domestic requirements of rice but also contributes a lot toward foreign exchange earning. Rice crop is suffering from water shortage and salinity in Egypt than other advanced rice growing countries of the World. To solve the problem of labour shortage and water shortage, alternate methods of rice stand establishment are inevitable. Direct seeding of rice is a potential alternate, which, is a successful method in various rice growing countries of the world (Adair et al., 1992). Direct seeding and bed planting of rice are considered as resource saving technologies in USA and Australia contributing a lot in reducing environmental pollution and enhancing livelihood of the farming communities through increasing profit with reduced cost of production (Awan et al., 2005, Majid et al., 1996; Sharma, 1996;). Bazaya et al (2009) found that the rice planting methods significantly affected bulk density, chemical traits and $\mathrm{pH}$ value

Attia et al .(2005 and 2006), Khattak et al.(2006) , Mishra, and Saha(2007) and Zayed et al.(2012) stated that rice bed planting and furrow irrigation gave high water use efficiency, high values saved water amount with considerable grain yield. Ndiiri et al (2012) found that the system of rice intensification (SRI) gave the highest values of yield and yield attributing traits as well as the highest values of root dry weight comparing with continues flooding for transplanted rice. Also they reported that SRI showed $27 \%$ of save water versus continues flooding in transplanting rice In the present investigation four rice planting methods were tested. It is an effort to achieve the sustainability and stability in rice production systems.

The current experiment aimed to study the efficiency of different rice planting systems in water saving with high sustainability of rice productivity and soil under saline soil.

\section{MATERIALS AND METHODS}

The experiments were conducted at the Rice Research and Training center, Rice program conducted at El Sirw Agriculture Research Station during 2011 and 2012 seasons. The experimental field was surrounded by rice fields in a relatively flat topography. The experimental soil was clay in texture. Other soil characteristics are shown in Table 1.

The tested systems of rice cultivation were traditional transplanted with watering every four days as traditional methods (control treatment) up to $6 \mathrm{~cm}$ water depth, system of rice intensification (SRI) with intermittent irrigation system, dry rice seed on dry levees (Furrows) with watering as 
upland crop up to 30 days after sowing then shifting watering every four days up to $1 \mathrm{~cm}$ water depth above the seed bed and transplanted rice on levees (Furrows) with watering every four days up to $1 \mathrm{~cm}$ water depth

$\mathrm{SRI}$ is the system of rice cultivation by using young seedling age(12 days old), spacing 20X20 with one seedling/hill, low seed rate and irrigation practices is intermittent irrigation in the terms of alternative wetting and drying.

The experiments were conducted in a randomized complete block design (RCBD) in four replications with plot size of about $200 \mathrm{~m}^{2}(10 \mathrm{~m}$ width $X 20 \mathrm{~m}$ length). The land surface (or bed) configurations consisted of conventional puddled flat fields (B0), and levees (Furrows) of $65 \mathrm{~cm}$ centreto-centre spacing (B65) with furrows $35 \mathrm{~cm}$ wide. Thus, the bed width was 30 $\mathrm{cm}$. The bed heights were about $20-25 \mathrm{~cm}$ from the furrow bottom. Irrigation water is applied in flats (B0) until the water depth reaches $6 \mathrm{~cm}$ above the soil surface each 4 days, and in beds (B65) until it reaches 1-2 cm above the bed surface. In levees reatment, the fields were irrigated when the water depth in the furrows was $10 \mathrm{~cm}$ below the bed surface.

\section{Experimental design and cultural practices}

All main plots were surrounded by consolidated bunds and lined with plastic sheets installed to a depth of $0.4 \mathrm{~m}$ to minimize seepage among plots. Beds of $30 \mathrm{~cm}$ width (B65 with furrow about $35 \mathrm{~cm}$ wide and $20 \mathrm{~cm}$ deep were formed using a bed shaper attached to a 4-wheel tractor under dry soil conditions. There were 15 beds in B65 plots of 20 m length within each plot. Plots assigned as bed treatments remained dry while the flat fields were soaked 2 weeks before transplanting for puddling under wet soil conditions.

Two days before transplanting, the beds were flooded up to $10 \mathrm{~mm}$, ponding water above the bed surface to facilitate transplanting. In all treatments standing water was maintained at $10-20 \mathrm{~mm}$ during the first 10 days after transplanting to facilitate seedling recovery. Afterwards, the ponded water layer in well water( traditional transplanting of rice) was kept between 30 and $60 \mathrm{~mm}$ before terminal drainage at 15 days before the harvest. In the other water treatments, water application was withheld depending on the treatment.

The recommended fertilizer application rates for $\mathrm{N}, \mathrm{P}$ and $\mathrm{K}$ were used. The rate of nitrogen application was $165 \mathrm{~kg} \mathrm{ha}^{-1}$ as Urea $46.5 \%$, Phosphorus at rate of $35 \mathrm{~kg} \mathrm{ha}^{-1}$ as single super phosphate, and potassium at $54 \mathrm{~kg} \mathrm{~K}_{2} \mathrm{O} \mathrm{ha} \mathrm{h}^{-1}$ as potassium sulfate. Zinc was applied at $24 \mathrm{~kg} \mathrm{ZnSO}$ $7 \mathrm{H}_{2} \mathrm{Oha}^{-1}$ in both seasons. $\mathrm{P}, \mathrm{K}$ and $\mathrm{Zn}$ were applied as basal dressings and incorporated in individual plots 1 day before transplanting. The cultivar used was Giza 178 in all seasons. Seedlings were grown in a seedling nursery for approximately 25 days. Transplanting was carried out by placing 2-3 plants per hill at a spacing of $20 \mathrm{~cm} \times 20 \mathrm{~cm}$ in flats. In levees the row spacing was set at $15 \mathrm{~cm}$, resulting in 3 rows in $B 65(30 \mathrm{~cm}$ bed width $+35 \mathrm{~cm}$ furrow width). At direct seeded methods, the seed had been sown at the same day of nursery establishment for transplanting method. The hill spacing along the rows was $18 \mathrm{~cm}$ in $\mathrm{B} 65$ to maintain a similar plant population ( 25 hills $\mathrm{m}^{-2}$ ), and no plants were grown in the furrows. 
Each plot was irrigated separately. The volume of irrigation water applied in each plot was measured by a flow meter. The depth of irrigation water applied (measured in $\mathrm{mm}$ ) over the plot surface was then computed from the volume of water applied and the area of the plot.

Soil was sampled at harvest, the part of it stored in the refrigerator for chemical analysis and the other for physical analysis according to,piper,(1950), Cottein et al. (1982) and Page et al. (1982) and Kemper and Rosenau (1986).

Soil analysis and measurements includes Soil EC dS $\mathrm{m}^{-1}$ in soil paste extract, soil $\mathrm{pH}$ in 1:2.5 soil water suspension, bulk density $\mathrm{kg} \mathrm{m}^{-3}$, soluble cations and anions meq liter ${ }^{-1}$

Data collected were, chlorophyll content( SPAD value), flowering date plant height in $\mathrm{cm}$, number of panicles per hill, filled grains panicle ${ }^{-1}$, unfilled grains panicle ${ }^{-1}$, panicle weight in $\mathrm{g}$, panicle length in $\mathrm{cm}$ and rice grain yield tha-1 at maturity. The grains were separated from the straw, and the grains were weighed. Grain yield was calculated based on the adjustment to grain moisture content of $140 \mathrm{~g} \mathrm{~kg}-1(\approx 14 \%)$.

\section{Water use efficiency (WUE):}

Water use efficiency was calculated according to Michael (1978). Data of each season were imposed to the statistical analysis of variance and differences among treatments means of the studied traits were judged by LSD at $\mathrm{P} \leq 0.05 \%$ level of significance according to Gomez and Gomez .(1984).

\section{RESULTS AND DISCUSSION}

\section{1-Soil properties:}

Tested rice cultivation systems markedly affected soil chemical and physical proprieties during the two seasons of study (Tables 1, 2and 3). Dry seed on dry levees gave the highest values of EC (6.0 and $\left.5.6 \mathrm{dS} \mathrm{m}^{-1}\right)$ in both seasons but it is still less than initial EC values $\left(6.4\right.$ and $\left.6.0 \mathrm{dS} \mathrm{m}^{-1}\right)$. The transplanted on levees came after dry seed on dry levees of EC values (5.8 and $5.4 \mathrm{dS} \mathrm{m}^{-1}$ ). In spite of the dry condition and using water in the furrow only without stand water on the top of levees in some time in the two first systems of rice cultivation the salinity didn't come up to initial one in the terms of no more salinization resulted from this system this may be due to drying flooding rotation. On the other hand, the system of rice intensification had the minimum values of EC in both seasons (Table1). On contrary, the rice planting method of dry seed on dry levees recorded the lowest value of $\mathrm{pH}$ which was less than the initial ones this may be due to $\mathrm{Cl}$ concentration in the furrows tops which increased due to water evaporation from the furrow top comparing with the other treatments $\left(43.4\right.$ and $\left.37.6 \mathrm{meq} \mathrm{L}^{-1}\right)$. The rest of rice cultivation system exceeded the initial $\mathrm{pH}$ in which, the highest one was produced by traditional transplanting that might be due to bad drainage system under continues flooding( Table 1). Regarding the cations and anions under the studied system of rice cultivation, the cations and anions showed the trend of EC where dry seed on dry levees (Furrows) had the 
highest values of $\mathrm{Na}^{+}\left(54.4 \& 50.2\right.$ meq $\left.\mathrm{L}^{-1}\right)$, The highest values of $\mathrm{Ca}^{+2}+\mathrm{Mg}^{+2}$ (6.10\&5.6 meq L $\left.{ }^{-1}\right)$ and the highest $\mathrm{Cl}$ values of $\left(43.40 \& 37.36 \mathrm{meq} \mathrm{L}^{-1}\right)$ in the first and second seasons, respectively (Tables 1 and 2 ).

Regarding the bulk density, the bulk density obviously differed under various systems of rice cultivation in both seasons (Table 3). The bulk density of all studied systems of rice cultivation showed marked decrease rather than initially obtained at the beginning of season. The system of rice intensification ( SRI) recorded the lowest values of bulk density in both seasons $\left(1.26 \& 1.25 \mathrm{~kg} \mathrm{~m}^{-3}\right)$ followed by the transplanted rice on levees $(1.290$ and $1.280 \mathrm{~kg} \mathrm{~m}^{-3}$ ). On the other hand, the dry seed in dry levees gave the highest values of bulk density in both seasons followed by traditional rice transplanting methods but they are still less the initial one (Table3). The alternative wetting and dry in the system of rice intensification might be improved soil chemical and physical properties such bulk density and reduced EC as a good drainage and aerobic condition resulted in improving soil quality by leaching salts colons and increasing root distribution and organic matter (Bazaya et al., 2009 and Ndiiri1 el al., 2012).

Table (1): Some soil chemical properties as affected by different rice planting systems under saline soil conditions.

\begin{tabular}{|l|c|c|c|c|c|c|c|c|}
\hline \multirow{2}{*}{ Trait } & \multicolumn{2}{|c|}{ EC, dS/m } & \multicolumn{2}{c|}{$\mathbf{p H}$} & \multicolumn{2}{c|}{$\mathbf{N a}^{+}, \mathbf{m e q} / \mathbf{l}$} & \multicolumn{2}{c|}{$\begin{array}{c}\mathbf{C a}^{++}+\mathbf{M g}^{++} \\
\mathbf{m e q} / \mathbf{l}\end{array}$} \\
\cline { 2 - 9 } Rice planting system & $\mathbf{2 0 1 1}$ & $\mathbf{2 0 1 2}$ & $\mathbf{2 0 1 1}$ & $\mathbf{2 0 1 2}$ & $\mathbf{2 0 1 1}$ & $\mathbf{2 0 1 2}$ & $\mathbf{2 0 1 1}$ & $\mathbf{2 0 1 2}$ \\
\hline Dry seed on dry & 6.0 & 5.6 & 8.30 & 8.28 & 54.4 & 50.2 & 6.1 & 5.6 \\
levees & 5.8 & 5.4 & 8.41 & 8.32 & 51.2 & 46.0 & 6.12 & 4.9 \\
Transp. on levees & 5.0 & 4.8 & 8.50 & 8.45 & 43.0 & 38.0 & 3.46 & 4.0 \\
SRI & 5.3 & 5.0 & 8.55 & 8.48 & 51.3 & 40.0 & 3.80 & 4.1 \\
Trad. Transplanting \\
Initial Ec and pH
\end{tabular}

Table (2): Some soil chemical properties as affected by different rice planting systems under saline soil conditions.

\begin{tabular}{|l|c|c|c|c|c|c|c|c|}
\hline \multirow{2}{*}{ Trait } & \multicolumn{2}{c|}{$\mathrm{K}^{+}, \mathbf{m e q} / \mathbf{l}$} & \multicolumn{2}{|c|}{$\mathrm{HCO}_{3}, \mathbf{m e q} / \mathbf{l}$} & \multicolumn{2}{c|}{$\mathrm{Cl}^{-1}, \mathbf{m e q} / \mathbf{l}$} & $\mathbf{S O}_{4}{ }^{-*}, \mathbf{m e q} / \mathbf{l}$ \\
\cline { 2 - 9 } Rice planting system & $\mathbf{2 0 1 1}$ & $\mathbf{2 0 1 2}$ & $\mathbf{2 0 1 1}$ & $\mathbf{2 0 1 2}$ & $\mathbf{2 0 1 1}$ & $\mathbf{2 0 1 2}$ & $\mathbf{2 0 1 1}$ & $\mathbf{2 0 1 2}$ \\
\hline Dry seed on dry & 0.30 & 0.36 & 2.25 & 2.13 & 43.4 & 37.36 & 19.9 & 16 \\
levees & 0.40 & 0.39 & 2.75 & 2.52 & 38.1 & 33.0 & 15.3 & 18 \\
Transp. on levees & 0.35 & 0.37 & 2.50 & 2.1 & 30.9 & 29.0 & 17.4 & 15 \\
SRI & 0.38 & 0.37 & 3.25 & 2.6 & 35.0 & 26.0 & 17.8 & 14 \\
Trad. Transplanting & & & & & & & & \\
\hline
\end{tabular}

Table (3): Bulk density as affected by different rice planting systems under saline Soil conditions.

\begin{tabular}{|l|c|c|l|l|}
\hline \multirow{2}{*}{ Rice planting system } & Trait & \multicolumn{2}{c|}{ Bulk density $\mathbf{( k g} / \mathbf{m}^{\prime}$} & \multicolumn{2}{c|}{ Soil texture class } \\
\cline { 2 - 5 } & $\mathbf{2 0 1 1}$ & $\mathbf{2 0 1 2}$ & $\mathbf{2 0 1 1}$ & $\mathbf{2 0 1 2}$ \\
\hline Dry seed on dry levees & 1.345 & 1.342 & Clay & Clay \\
Transp. on levees & 1.293 & 1.289 & Clay & Clay \\
SRI & 1.260 & 1.251 & Clay & Clay \\
Trad. Transplanting & 1.300 & 1.297 & Clay & Clay \\
Initial bulk density & 1.351 & 1.345 & Clay & Clay \\
\hline
\end{tabular}




\section{2-Yield and yield components}

The tested rice cultivation system significantly affected the growth, yield attributes in both seasons (Tables 4,5, 6 ). Furthermore, the different systems of rice cultivation significantly influenced rice grain yield in the two seasons of study(Table 7). The system of rice intensification (SRI) gave the highest values of chlorophyll content at heading (45.3 and 43.0), panicle length $(2.0$ and $21.9 \mathrm{~cm})$, panicle number hill ${ }^{-1}(18.1$ and 18.7), panicle weight $(3.16$ and $3.38 \mathrm{~g})$, filled grains /panicle, lowest values of unfilled grains /panicle and ultimately the highest values of rice grain yield. Interestingly, both treatments of SRI and traditional transplanted rice were at the same level of significance regarding chlorophyll content, panicle length, panicle number /hill, panicle weight, 1000 grain weight and rice grain yield. The heaviest 1000 grain weight and tallest plants were produced by traditional transplanted rice on flat soil in both seasons (Tables4, 5, 6 and 7). On the other hand, the minimum means of yield and yield contributes were obtained under system of dry seed on dry levees. It is mentioning here that the tested rice planting system significantly varied in their flowering date in both seasons. The system of dry seed on dry levees gave the shortest period from sowing to heading ( 90.0 \& 89.0 days) in the first and second seasons, respectively. On the other hand the traditional transplanting gave the longest period from sowing to heading ( 100.0 \& 100.7 days) in 2011 and 2012 seasons, respectively. Similar finding had been reported by Attia et al.(2005 and 2006), , Waled et al.(2009), Ndiiri1 el al., ( 2012) and Zayed et al.,(2012).

Table (4): Some growth parameters of Giza 178 rice variety as affected by rice planting system under saline soil conditions .

\begin{tabular}{|l|c|c|c|c|c|c|}
\hline \multirow{2}{*}{ Trait } & \multicolumn{2}{|c|}{$\begin{array}{c}\text { Chlorophyll } \\
\text { content, SPAD } \\
\text { value }\end{array}$} & \multicolumn{2}{|c|}{ Flowering date } & \multicolumn{2}{|c|}{ Plant height (cm) } \\
\cline { 2 - 7 } Rice planting system & $\mathbf{2 0 1 1}$ & $\mathbf{2 0 1 2}$ & $\mathbf{2 0 1 1}$ & $\mathbf{2 0 1 2}$ & $\mathbf{2 0 1 1}$ & $\mathbf{2 0 1 2}$ \\
\hline Dry seed on dry levees & 40.7 & 39.0 & 90.0 & 89.3 & 86.8 & 87.0 \\
Transplanted on levees & 42.5 & 40.0 & 99.3 & 99.0 & 93.6 & 93.0 \\
SRI & 45.3 & 43.0 & 95.1 & 94.0 & 92.5 & 91.3 \\
Traditional transplanting & 44.0 & 42.2 & 100.0 & 100.7 & 96.3 & 95.0 \\
LSD0.05 & 1.6 & 1.12 & 3.25 & 3.7 & 2.71 & 1.84 \\
\hline
\end{tabular}

Table (5): Some yield attributes of Giza 178 rice variety as affected by rice planting system under saline soil conditions.

\begin{tabular}{|l|c|c|c|c|c|c|}
\hline \multirow{2}{*}{ Trait } & \multicolumn{2}{|c|}{$\begin{array}{c}\text { Panicle } \\
\text { length(cm) }\end{array}$} & \multicolumn{2}{c|}{ Panicle No hill $^{-1}$} & \multicolumn{2}{c|}{ Panicle weight g } \\
\cline { 2 - 7 } Rice planting system & $\mathbf{2 0 1 1}$ & $\mathbf{2 0 1 2}$ & $\mathbf{2 0 1 1}$ & $\mathbf{2 0 1 2}$ & $\mathbf{2 0 1 1}$ & $\mathbf{2 0 1 2}$ \\
\hline Dry seed on dry levees & 20.13 & 20.31 & 15.80 & 16.25 & 2.62 & 2.74 \\
Transplanted on levees & 21.40 & 21.60 & 17.00 & 17.40 & 3.13 & 3.25 \\
SRI & 22.00 & 21.90 & 18.10 & 18.70 & 3.16 & 3.38 \\
Traditional transplanting & 21.90 & 21.80 & 17.76 & 17.61 & 2.90 & 3.10 \\
LSD0.05 & 0.64 & 0.57 & 1.50 & 1.31 & 0.42 & 0.40 \\
\hline
\end{tabular}


Table (6): Some yield components of Giza 178 rice variety as affected by rice planting system under saline soil conditions

\begin{tabular}{|l|c|c|c|c|c|c|}
\hline \multirow{2}{*}{ Trait } & \multicolumn{2}{|c|}{$\begin{array}{c}\text { Filled grains } \\
\text { /panicle }\end{array}$} & \multicolumn{2}{c|}{$\begin{array}{c}\text { Unfilled grains } \\
\text { Number }\end{array}$} & $\begin{array}{c}\mathbf{1 0 0 0}-\mathbf{g r a i n} \text { weight } \\
\mathbf{( g )}\end{array}$ \\
\cline { 2 - 7 } Rice planting system & $\mathbf{2 0 1 1}$ & $\mathbf{2 0 1 2}$ & $\mathbf{2 0 1 1}$ & $\mathbf{2 0 1 2}$ & $\mathbf{2 0 1 1}$ & $\mathbf{2 0 1 2}$ \\
\hline Dry seed on dry levees & 125.0 & 128.0 & 17.20 & 14.5 & 18.73 & 18.37 \\
Transplanted on levees & 128.0 & 131.0 & 16.10 & 14.0 & 18.60 & 18.51 \\
SRI & 136.0 & 138.0 & 10.00 & 8.5 & 19.50 & 19.75 \\
Traditional transplanting & 134.0 & 133.0 & 11.33 & 9.6 & 20.60 & 20.33 \\
\hline LSD0.05 & 2.17 & 2.6 & 2.57 & 1.78 & 0.80 & 0.71 \\
\hline
\end{tabular}

Under flooded conditions, despite the fact that ample water is available to the rice plant, there are numerous constraints introduced in terms of nitrogen supply. Lowland rice generally loses more than $60 \%$ of applied nitrogen through ammonia volatilization from the floodwater (Ceesay et al., 2006). Microbial activity is reduced, and as a result, the decomposition of soil organic matter is reduced by $50 \%$ under anaerobic conditions. Zinc deficiency has been reported as a widespread nutritional disorder in flooded rice. Further, recent research is showing that in continuously flooded rice soils, much of the nitrogen in soil organic matter becomes bonded to aromatic rings and thus is not readily available to the crop (Schmidt-Rohr et al., 2004). The microbial biomass nitrogen is an important repository of plant nutrients that is more labile than the bulk of soil organic matter and able to contribute substantial amounts of nutrients in the soil. Of the factors that contribute to high nitrogen availability and high nitrogen use-efficiency under SRI management practices, repeated wetting and drying process may have the greatest influence.

SRI's water management practices of intermittent irrigation also help in improving root systems (Bouman et al. 2005). According to Kirk and Soilivas, (1991), $75 \%$ of roots of rice plants growing in continuously flooded soil remain shallow, in the top $6 \mathrm{~cm}$.

Continues flooding can also cause degeneration of as much as threefourths of a rice plant's roots by the flowering stage (Kar et al., 1974). This degenerative physiological process presumably has some limiting effect on rice plant performance (Kirk \& Bouldin, 1991).

Table (7): Grain yield ( $\mathrm{t} \mathrm{ha}{ }^{-1}$ ) and Total applied water $\mathrm{m}^{3} \mathrm{ha}^{-1}$ of Giza 178 rice variety as affected by rice planting under saline soil conditions.

\begin{tabular}{|l|c|c|c|c|}
\hline \multirow{2}{*}{ Trait } & \multicolumn{2}{|c|}{ Grain yield,( t/ha) } & \multicolumn{2}{c|}{ Total applied water } \\
\cline { 2 - 5 } Rice planting system & $\mathbf{2 0 1 1}$ & $\mathbf{2 0 1 2}$ & $\mathbf{2 0 1 1}$ & $\mathbf{2 0 1 2}$ \\
\hline Dry seed on dry levees & 7.72 & 8.09 & 8899.0 & 8910.0 \\
Transplanted on levees & 7.81 & 8.03 & 9413.8 & 9306.0 \\
SRI & 8.36 & 8.68 & 10608.4 & 10593.0 \\
Traditional transplanting & 8.25 & 8.69 & 13618.0 & 13629.0 \\
\hline LSD0.05 & 0.49 & 0.39 & - & - \\
\hline
\end{tabular}

\section{3-Water measurements}

FAO, (2006) indicate that a $1 \%$ increase in water productivity in food production makes available extra 24 liters of water per day per capita. 
Investing in agriculture and in agricultural water management, therefore, is an attractive strategy for freeing water for other purposes.

Water scarcity is likely to become a more significant problem around the world. Adopting cultivation practices such as dry seed on dry levees, rice on bed and SRI that use less water is the way forward.

Regarding water measurements in the current investigation, the system of dry seed on dry levees gave the lowest values of total applied water (8899.0 \&8910.0 $\left.\mathrm{m}^{3} / \mathrm{ha}\right)$ in the first and second seasons, respectively followed by transplanted rice on levees and then SRI in both seasons(Table 7 ). In addition, dry seed on dry levees had the highest values of water use efficiency and water saved (0.87 and 0.91 as well 4290) for WUE, water saved in 2011 and 2012 seasons, respectively, followed by rice transplanted on levees and then SRI(Table9). Traditional rice transplanting of flat soil gave the highest values of total applied water $\left(13618 \& 13629 \mathrm{~m}^{3} / \mathrm{ha}\right)$ and the lowest values of water use efficiency $(0.61$ and 0.64$)$ in the first and second seasons, respectively. Considering soil, yield and water saved, the SRI superior the rest of current investigated system of rice cultivation under present conditions. Similar results had been indicated by Ndiiri1 el al., ( 2012) and Zayed et al.,(2012) )

Table(8):Water productivity of rice as influenced by different systems of rice cultivation in saline soil conditions.

\begin{tabular}{|l|c|c|c|c|}
\hline \multirow{2}{*}{ Treatments } & \multicolumn{2}{c|}{ WUE $\mathbf{~ k g ~ r i c e ~ / \mathbf { m 3 ~ }}$} & \multicolumn{2}{c|}{ Water saved $\mathbf{~}$ /ha } \\
\cline { 2 - 5 } & $\mathbf{2 0 1 1}$ & $\mathbf{2 0 1 2}$ & $\mathbf{2 0 1 1}$ & $\mathbf{2 0 1 2}$ \\
\hline Dry seed on dry levees & 0.87 & 0.91 & 4290 & 4290 \\
Transplanted on levees & 0.83 & 0.86 & 3822 & 3930 \\
SRI & 0.79 & 0.81 & 2736 & 2760 \\
Traditional transplanting & 0.61 & 0.64 & - & \\
\hline
\end{tabular}

WUE= water use efficiency

\section{REFERENCES}

Adair, C. R., H.M Beachell.; N. E. Jodon; L. L. David and . J. W. Jones (1992). Comparative yields of transplanted and direct sown rice, J. Amer. Soc. Agron. 34(2): 129-127.

Atta, Y.I.M. (2005). Strip planting of rice: A new method for increasing water use efficiency under splitting of nitrogen fertilizer. Egypt. J. of Appl. Sci, 20 (10B): 501-511.

Atta, Y. I. M.;. M.E Meleha, A. Tallet and U.M. Gawish (2006). Improving water productivity in rice cultivation with high potential for water saving. The 3rd Arab World Region Conference, Cairo, 4-11 December.

Awan, T. H., I. Ali, C. M. Anwar, G. M. Sarwar, C. M. Ahmad, Z. Manzoor and M. Yaqub.(2005). Economic Effect of Different Plant Establishment Techniques on Rice Production. In Proc. Int. Seminar on Rice Crop, RRI, KSK, Lahore, Punjab - Pakistan. 2-3, October 2005. pp: 226-231.

Bazaya, B.R. S.,Avijit and M. Srivastava (2009). Planting methods and nitrogen effects on crop yield and soil quality under direct seeded rice in the Indo-Gangetic plains of eastern India, Soil and Tillage Research, 105 (1): 27-32. 
Black, G.R., and K.H., Hartge (1986). Bulk density. In: A. Klute (Ed.). Methods of Soil Analysis. Part I. Physical and Mineralogical Methods. 2nd. Ed., Agronomy No. 9 (part I). ASA-SSSA. Madison, Wisconsin, USA, 363-375.

Bouman BA, S. Peng, A.R. Castañeda and R. M.Visperas (2005). Yield and water use of irrigated tropical aerobic rice systems. Agricultural Water Management, 74:87-105.

Ceesay M, W.Reid, E. Fernandes and N. Uphoff (2006).The effects of repeated soil wetting and drying on lowland rice yield with System of Rice Intensification (SRI) methods. International Journal of Agricultural sustainability; 4 (1): 5-14.

Cottenie, A.; P.M. Verloo; L. Kiekens; G. Velghe and R.Camerlynek (1982). Chemical Analysis of Plants and Soils. Lab. Anal. Agrochem. State Univ., Gent. Belgium.

FAO.(2006). Raising water productivity. Spotlight Magazine Rome FAO 2006; AG21.

Gomez, K.A.anbd A.A. Gomez (1984). Statistical procedures for agricultural research $.2^{\text {nd }}$. ed, John wiley and Sons, USA.

Kar S, SB. Varade, TK. Subramanyam and BP.Ghildyal (1974). Nature and growth pattern of rice root system under submerged and unsaturated conditions, Italy. II Riso 23:173-179.

Kemper, W.D., and R.C. Rosenau (1986). Aggregate stability and size distribution. Methods of Soils Analysis. Part I. Physical and mineralogical methods. American Society of Agronomy, Madison, Wisconsin. pp: 425-444

Khattak, S. I.; K. Usman ; Q. Khan and A. Qayyum (2006). Impact of various planting techniques on yield and yield components of rice. India Journal of Plant Sciences. 5(1): 753-756.

Kirk GJD and DR. Bouldin ( 1991). Speculations on the operation of the rice root system in relation to nutrient uptake. In. Penning de Vries FWT et al. eds. Simulation and Systems Analysis for Rice Production. Wageningen: Pudoc; 195-203.

Majid, A., A. S. Kahan, S. I.Ahmad and M. A. Zaid (1996). Water consumption of Different Rice Production Techniques. AMA, Agricultural Mechanization Asia, Africa and Latin America 27(1): 37-40 (Rice Absts., 19(4): 2457; 1996).

Michael, A.M. (1978). Irrigation theory and practices. Vikas Publishing House PUTLTD New Delhi, Bombay.

Mishra, V. and R. Saha (2007). Effect of raised sunken bed system on interplot water harvesting and productivity of rice and French bean in Meghalaya. Indian J. of Agric. Sci. 77 (2): 73-78.

Ndiiri1, J.A., B.M. Mati, P.G. Home, B. Odongo and N. Uphoff( 2012). Comparison of water saving of paddy rice under system of rice intensification(SRI) growing RICE in Mwea, Kenya. International Journal of Current Research and Review www.ijcrr.com , I(4):63-73.

Page, A.L.; R.H. Miller and D.R. Keeney (1982). Methods of Soil AnalysisPart 2- Amer. Soc. Agric. Inc. Madison. 
Zayed, B. A. et al.

Piper, C.S. (1950). Soil and Plant Analysis. Inter-science Publisher. Inc. New York., USA.

Sharma, A. R. (1996). Direct seeding and transplanting for rice production under flood prone lowland conditions. Field Crop Res. 44(2-3): 129137.

Waled M. Elkhoby; Abd Allah A. Abd Allah; E. M. Okasha and Alaa Z. ElBably(2009). Rationalization of Irrigation Water Use in Some Rice Cultivars Using Different Planting Methods in North Delta, Egypt. J. of plant and environment science 2 (2009) 79-85.

Zayed, B.A, A. M. El-Khtyar, A. G.Metwaly and W.H Abou El Hassan (2012). Water use efficiency and rice productivity as affected by new planting methods at northern part of Delta of Egypt. Egypt. J. Agric. Res.,90(4):264-274.

تـاثيرنظم زراعـة الأرز علـي الأرض و الميـاة و المحصـول بأراضسي شـــال الـلتـا

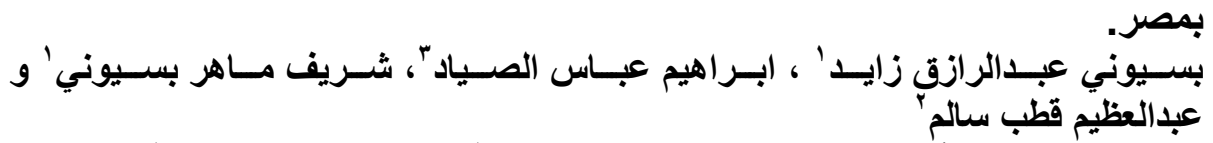

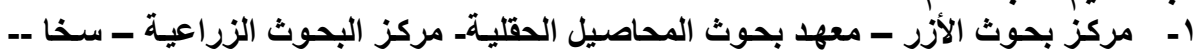

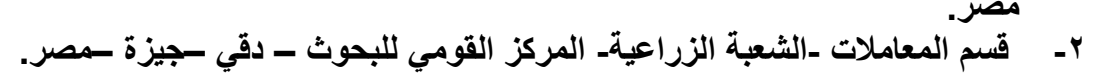

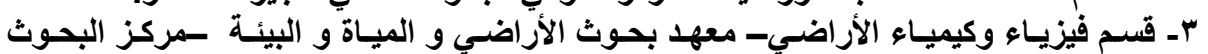
الزراعيةت سخا- مصر.

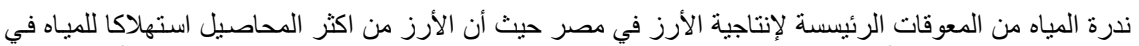

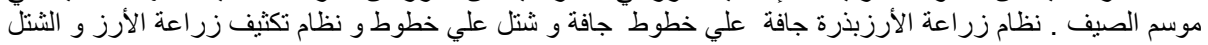

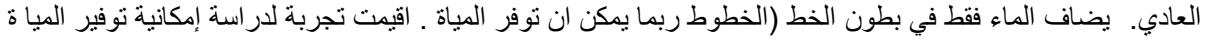

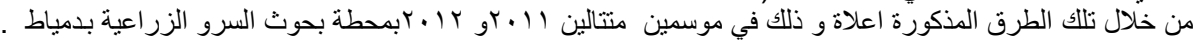

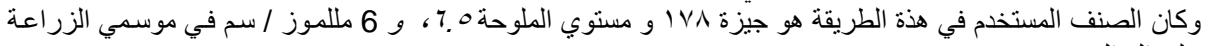
علي التو الي. - اليف ويمكن تلخيص أهم النتائج في الأتي.

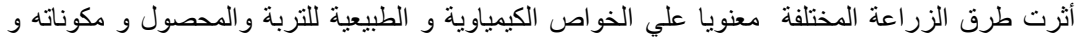

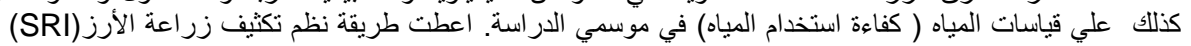

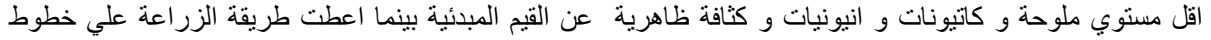

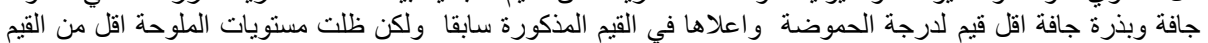

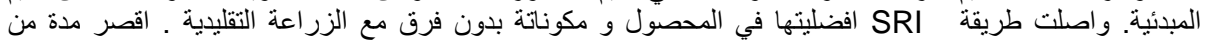

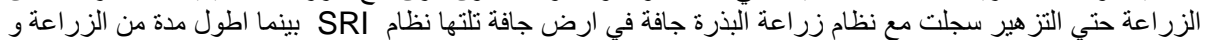

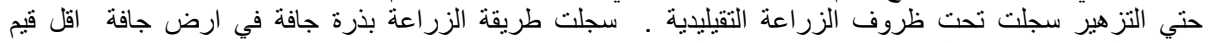

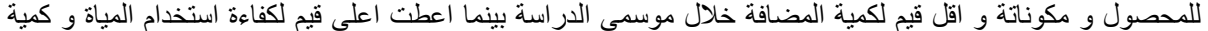

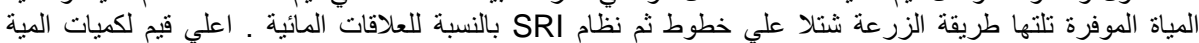

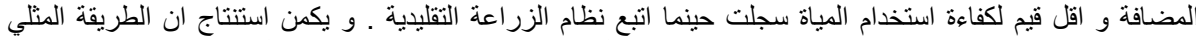
للزر اعة هنا هي SRI باعتبار التاثير علي التربة و المحصول و توفير المياة مع زيادة المحصول.

$$
\text { كلية الزراعة - جامعة المنصورة }
$$

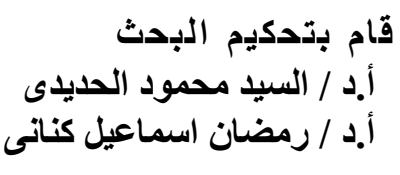

قام بتدكيم البحث

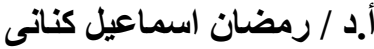

